Theor Appl Genet (1992) 84: 866-873

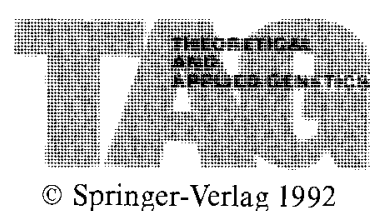

(1) Springer-Verlag 1992

\title{
Impact of the stringency of cell selection on plastid segregation in protoplast fusion-derived Nicotiana regenerates
}

\author{
R. Malone ${ }^{1,2}$, G. V. Horváth ${ }^{1}$, A. Cséplö ${ }^{1}$, B. Búzás ${ }^{1}$, P. J. Dix ${ }^{2}$, and P. Medgyesy ${ }^{1}$ \\ 1 Biological Research Centre, Hungarian Academy of Sciences, P.O. Box 521, H-6701 Szeged, Hungary \\ 2 Department of Biology, St. Patrick's College, Maynooth, Co. Kildare, Ireland
}

Received December 7, 1991; Accepted February 26, 1992

Communicated by Yu. Gleba

\begin{abstract}
Summary. Vegetative segregation of a mixed plastid population in protoplast fusion-derived cell lines can be directed by a selection favouring the multiplication of one of the parental plastid types. This report defines some of the critical conditions leading to a homogeneous plastid population in cybrid plants generated by protoplast fusion between Nicotiana plumbaginifolia and an albino and streptomycin-resistant $N$. tabacum plastid mutant. Light $(1,500 \mathrm{~lx})$ conferred a strong selective advantage to chloroplasts versus albino plastids, while the lack of this effect in dim light $(300 \mathrm{~lx})$ indicated that a sufficient light intensity is essential to the phenomenon. Selection on streptomycin-containing medium in the dark, however, led to the preferential multiplication of resistant plastids. Streptomycin selection of resistant chloroplasts in the light, consequently, results in a plastid selection of doubled stringency. In another experiment a definite, but leaky, selection for chloroplast recombination (selection for greening on streptomycin-containing medium in dim light) was used to reveal various recombination products. Protoplast fusion in fact resulted in cybrid plants showing only simple chimeric segregation of unchanged parental plastids. These results demonstrate the essential requirement for stringent plastid selection, as defined by cell culture conditions, to precede the formation of shoots expected to possess the desired plastid genetic composition.
\end{abstract}

Key words: Nicotiana - Plastid genetic markers - Plastid segregation - Plastid selection - Protoplast fusion

Correspondence to: P. Medgyesy

\section{Introduction}

Higher plant cells may contain hundreds of chloroplasts (Butterfass 1979) which are generally inherited cytoplasmically, thus avoiding mixing with plastids of the pollen donor plant (Tilney-Bassett 1978). The advent of protoplast fusion techniques has enabled researchers to demonstrate the validity of the laws of behaviour of mixed organelle populations which were established in unicellular eukaryotes (Birky 1978). These include the vegetative segregation of plastids after protoplast fusion, followed by random fixation of pure parental or variously mixed plastid populations during the subsequent cell generations. Segregation of a mixed plastid population in heterokaryon-derived cell lines has proven to be a protracted process gradually resulting in random clumps of cells with one or the other, or a mixed, plastid population (Menczel et al. 1981; A kada et al. 1983; Akada and Hirai 1983). Since shoot regeneration occurs from a restricted group of cells within a callus, a similarly random distribution of (pure or mixed) plastid populations was detected in regenerated plants (Chen et al. 1977; Belliard et al. 1978; Melchers et al. 1978; Fluhr 1983; Medgyesy 1990). The use of plastid genetic markers proved to be especially suitable to demonstrate that the majority of the fusionderived cell lines may regenerate into plants which contain subpopulations of cells with different parental plastid populations (Gleba 1979; Fluhr et al. 1983; Gleba et al. 1984). If predictions on the behaviour of plant organelles are also in line with the terms of intracellular population genetics, plant cell cultures should offer a unique tool to manipulate plastid behaviour following protoplast fusion, by application of a selection pressure on plastid segregation during the course of the cell divisions preceding morphogenesis. The exploitation of the selective advantage of plastid populations which are resistant to 
streptomycin (Medgyesy et al. 1980; Menczel et al. 1982) and lincomycin (Cséplő et al. 1984), or are able to green against the background of light-sensitive (Glimelius and Bonnett 1981; Medgyesy et al. 1985b) and albino (Menczel et al. 1986) plastids, has indeed already been the key to the production of stable cybrid plants possessing a prescribed plastid population. Here we attempt to define some of the critical factors leading to the production of protoplast fusion-derived Nicotiana plants with a homogeneous plastid population. To this end we have examined cell culture conditions which influence plastid segregation, and have compared these effects with the available data on plastid selection.

\section{Materials and methods}

Plant lines

Both wild-type and a terbutryn-resistant (TBR2) plastid mutant (Cséplö et al. 1985) of Nicotiana plumbaginifolia Viviani were maintained as shoot cultures on RM salts (Murashige and Skoog 1962) with $2 \%$ sucrose and $0.7 \%$ Bacto-Agar (RM medium) in the light $\left(1,500 \mathrm{~lx}, 16-\mathrm{h}\right.$ day, $\left.26^{\circ} \mathrm{C}\right)$. An albino and streptomycin-resistant plastid mutant (SR-A15) of $N$. tabacum L. cv. Petit Havana (Sváb and Maliga 1986) was maintained as shoot cultures on RM medium supplemented with thiamine$\mathrm{HCl}(1 \mathrm{mg} / 1)$ and 1-naphthaleneacetic acid $(0.1 \mathrm{mg} / \mathrm{l})$ in $\mathrm{dim}$ light (300 lx, 16-h day).

\section{Protoplast fusion}

Leaf protoplasts were isolated from aseptically grown plants in a solution of $1 \%$ cellulase R10 and $0.3 \%$ macerozyme R10 dissolved in K3 medium (Nagy and Maliga 1976) containing $0.4 \mathrm{M}$ sucrose as the only osmoticum, as described previously (Menczel et al. 1981). Protoplasts of the cytoplasm donor in a given experiment were irradiated with a dose of $200 \mathrm{~J} / \mathrm{kg}$ of ${ }^{60} \mathrm{Co}$ gamma rays $(0.066 \mathrm{~J}$ per $\mathrm{kg}$ per $\mathrm{s}$ dose rate) according to the procedure of Menczel et al. (1982). Protoplasts were fused by polyethylene glycol (PEG) treatment as described earlier (Menczel et al. 1981), but with differences in the ratio of the protoplast mixture (1:1) and the time of PEG treatment (25 min).

\section{Cell culture}

Fused protoplasts were initially cultured in liquid K3 medium, and for selection the colonies were further grown in solid RMOP medium (Cséplö and Maliga 1984) as described previously (Medgyesy et al. 1985 b). In the case of streptomycin selection the solid medium was supplemented with streptomycin sulphate $(1 \mathrm{~g} / 1)$. Specific features of the selection and shoot regeneration in the particular experiments are described in the Results section. Shoots were regenerated as described earlier (Medgyesy et al. $1985 \mathrm{~b}$ ), but in poorly regenerating calli shoot formation was stimulated by adding silver nitrate $(50 \mathrm{mg} / \mathrm{l})$ to the regenerating medium (Purnhauser et al. 1987). Green and albino shoots were maintained on the appropriate RM medium (see above).

\section{Resistance test}

The terbutryn resistance of the regenerates was tested in a photomixotrophic culture (Cséplö and Medgyesy 1986) on RM medium with $0.3 \%$ sucrose in the light $(1,500 \mathrm{~lx})$. Bleaching of the shoots in the presence of $10^{-4} \mathrm{M}$ terbutryn after 4 weeks indicated their sensitivity to the herbicide, while the resistant shoots remained green. The natural tentoxin resistance and sensitivity of $N$. tabacum and $N$. plumbaginifolia plastids, respectively, were measured in a seedling test (Durbin and Uchytil 1977). Resistant seedlings, germinated on filter paper wetted with a tentoxin solution $(20 \mathrm{mg} / \mathrm{l})$, formed green cotyledons in 2 weeks, in contrast to the bleaching of sensitive ones. Streptomycin resistance was determined by a leaf test (Medgyesy et al. 1980 ) using streptomycin-containing RMOP medium with $2 \%$ sucrose in the light $(1,5001 \mathrm{x})$. Resistant leaf pieces remained green and formed green, regenerating, calli in 4 weeks. The formation of white calli and a gradual bleaching of the leaf pieces indicated a sensitivity of the plant tested.

\section{Organelle DNA analysis}

Chloroplasts and mitochondria were isolated from ground leaves of aseptically grown plants by differential centrifugation $(1,300 \times \mathrm{g}$ and $18,700 \times \mathrm{g}$, respectively $)$ in a high ionic strength buffer according to Bookjans et al. (1984). Lysis of chloroplasts and DNase-treated mitochondria, and the purification of DNA by phenol-chloroform deproteinization, followed standard protocols (Sambrook et al. 1989). Restriction enzyme digestions were performed according to the instructions of the supplier (Boehringer Mannheim GmbH). DNA fragments were separated by horizontal agarose-slab gel electrophoresis, and photographed in short wave UV light following ethidium bromide staining (Sambrook et al. 1989).

\section{Results}

Light gives a selective advantage to chloroplasts versus albino plastids in cell culture

Lethally irradiated protoplasts of normal green $N$. plumbaginifolia TBR2 were fused with protoplasts of the albino plastid mutant $N$. tabacum SR-A15. Cybrid clones were isolated on the basis of their greening ability under different light conditions $(1,500 \mathrm{~lx}$ and $300 \mathrm{~lx})$. The number of green colonies were similar in both fusion-derived cell cultures (Table 1). Shoot regeneration (performed under the same light conditions), however, revealed a striking difference in the proportion of pure cybrid lines. Calli derived from colonies grown under higher light intensity formed exclusively green shoots in $94 \%$ of the lines, while in the remaining cases some variegated shoots appeared among green ones (Table 1). In contrast, in the lines derived from the cultures grown under low light intensity only half of the clones represented pure chloroplast transfer because $38 \%$ of the calli produced variegated and/or white shoots in addition to green ones, while in $11 \%$ of the cases only albino shoots appeared from the calli (although these calli generally contained green sectors). Twenty green shoots (each from a different line) were tested for the presence of the donor plastid marker and proved to be resistant to terbutryn. The plants were potted in the greenhouse and had N. tabacum morphology but, in each case, formed male-sterile flowers (Fig. 1) and inherited this trait in a stable cytoplasmic manner. The organelle composition of two of them was also inves- 
Table 1. Plastid composition of shoots regenerated from differently selected protoplast fusion-derived cybrid lines

\begin{tabular}{|c|c|c|c|c|c|c|c|c|}
\hline \multicolumn{2}{|l|}{ Fusion combinations } & \multirow[t]{2}{*}{$\begin{array}{l}\text { Colony } \\
\text { selection }\end{array}$} & \multirow[t]{2}{*}{$\begin{array}{l}\text { Light } \\
\text { regime }\end{array}$} & \multicolumn{2}{|c|}{ Number of colonies } & \multicolumn{3}{|c|}{$\begin{array}{l}\text { Distribution of calli as for } \\
\text { shoot pigmentation }\end{array}$} \\
\hline Cytoplasm donor ${ }^{a}$ & Nucleus donor & & & Total & Selected & Green & Mixed $^{\mathrm{d}}$ & Albino \\
\hline N. plumbaginifolia TBR2 ${ }^{\mathrm{b}}$ & N. tabacum SR-A15 ${ }^{\mathrm{c}}$ & Greening & $1,5001 \mathrm{x}$ & $5.1 \times 10^{4}$ & 130 & 122 & 8 & 0 \\
\hline N. plumbaginifolia TBR2 & N. tabacum SR-A15 & Greening & $300 \mathrm{~lx}$ & $4.9 \times 10^{4}$ & 99 & 50 & 38 & 11 \\
\hline N. tabacum SR-A15 & N. plumbaginifolia & $\begin{array}{l}\text { Growth on } \\
\text { streptomycin }\end{array}$ & Dark & $6.4 \times 10^{4}$ & 20 & 0 & 1 & 19 \\
\hline N. plumbaginifolia TBR2 & N. tabacum SR-A15 & $\begin{array}{l}\text { Greening on } \\
\text { streptomycin }\end{array}$ & $3001 x$ & $3.2 \times 10^{4}$ & 1 & 0 & 1 & 0 \\
\hline
\end{tabular}

a Irradiated with a lethal dose of gamma rays

b Normal green, terbutryn-resistant plastid mutant

- Albino and streptomycin-resistant double plastid mutant

¿ Calli with green and albino and/or variegated shoots

tigated by restriction endonuclease digestion of organelle DNA. The plants contained $N$. plumbaginifolia TBR2 chloroplasts and recombined mitochondrial genomes (data not shown).

Streptomycin resistance is suitable for the growth selection of cell lines with resistant plastids

For the reverse fusion, in which the albino and streptomycin-resistant $N$. tabacum SR-A15 mutant was the irradiated parent, wild-type $N$. plumbaginifolia was used as the recipient. Fusion-derived cell cultures were grown in streptomycin-containing medium in the dark to reveal the effect of streptomycin selection on plastid transfer. Rapidly growing, white colonies were isolated against the background of slow growing, brownish ones, and were re-tested in the dark on streptomycin-containing medium. The best growing, healthy calli were further cultured on drug-free medium in the light $(1,500 \mathrm{~lx})$. Completely white shoots were produced marking the presence of $N$. tabacum SR-A15 plastids; only one of the 20 calli tested also produced a variegated shoot (Table 1). Each of the calli, however, contained light-green (non-regenerating) sectors. The characteristic morphology of $N$. plumbaginifolia demonstrated the cybrid nature of all the white plantlets (Fig. 2).

Plastid segregation dominates over genetic recombination if cell selection is of low stringency

The above results suggested a possible strategy to encourage the retention of different segregation products after plastid recombination. $N$. tabacum SR-A15 protoplasts were again fused with lethally irradiated protoplasts of $N$. plumbaginifolia TBR2, but then green cell colonies were selected in streptomycin-containing medium in dim light $(300 \mathrm{~lx})$. Under these conditions cell lines with a parental or a mixed plastid population were expected to be bleached because of albinism/sensitivity. Plas- tids with a recombination of greening ability and streptomycin resistance might, however, enable particular cell lines to green. On the other hand, the persistence of white sectors of segregating tissues/shoots should also be facilitated because of the lower stringency of selection. A single green colony appeared (Table 1) which, when retested on streptomycin-containing medium, formed sectorial (green and white) callus and showed early regeneration of shoots (also sectorial). A subculture onto drugfree medium revealed the development of green, variegated, and truly albino shoots. Each of the regenerated plants had N. tabacum morphology. According to their leaf pigmentation, stable chimeras showing tissue layer (L1, L2 and/or L3)-specific segregation of green and white leaf areas were obtained in addition to parental (completely green or white) types. Using the nomenclature of Tilney-Bassett (1986) they could be classed as "thick skinned" (Fig. 3), "sandwich" (Fig. 4) and "thin skinned" (Fig. 5A-E) periclinal chimeras. In a leaf test for greening each of the green or partly green plants, surprisingly, proved to be completely sensitive to (i.e., fully bleached by) streptomycin (Fig. 5C). In addition, in a shoot test all the green shoots were resistant to terbutryn. In an $F_{1}$ progeny test these plants demonstrated tentoxin sensitivity (also an $N$. plumbaginifolia plastid trait) with no sign of segregation of green sectors in the cotyledons $(150-200$ seedling tested in a subline). On the other hand, the calli induced from white leaves or white leaf parts showed a streptomycin-resistant growth in the dark (data not shown). Altogether, the genetic markers indicated the presence of pure parental-type plastids (or their simple mixtures) in the regenerates, as in simple chloroplast transfer experiments. The cybrid nature of green plants was further supported by the typical alloplasmic male sterility of their flowers (phenotypically identical to those of the cybrids described in the first section). The restriction endonucleases, which distinguished between the digestion patterns of $N$. tabacum 

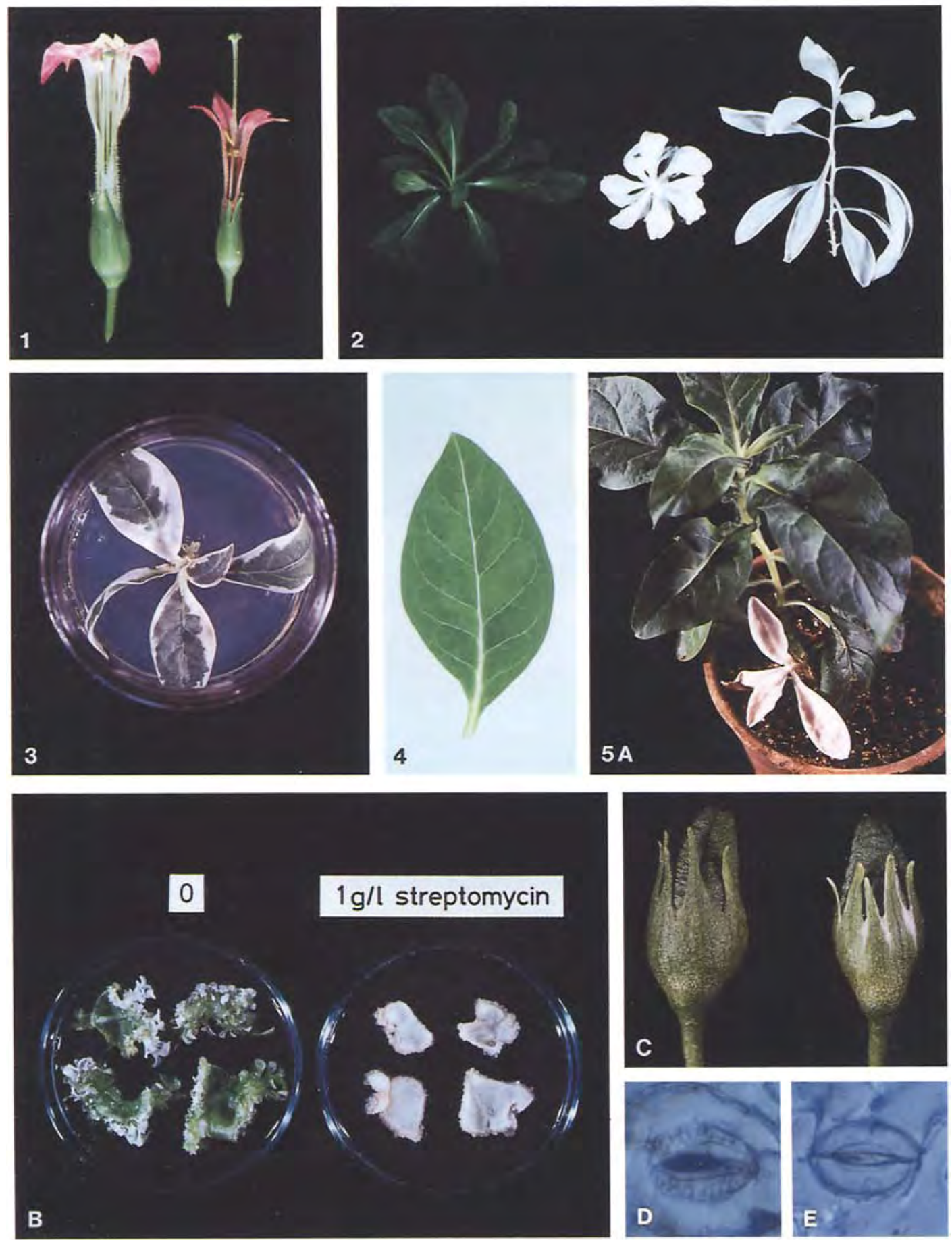

Plate (Figs. 1-5) 1. Longitudinal section of flowers of wild-type Nicotiana tabacum (left) and a fusion-derived cybrid (right) containing the cytoplasm of $N$. plumbaginifolia. Alloplasmic male sterility appears as shortened stamens (and a corolla) and the production of sparse pollen. 2. Morphology of in vitro-grown (from left to right) wild-type $N$. plumbaginifolia (leaves in a rosette), a fusion-derived cybrid, and albino $N$. tabacum SR-A15 (long internodes). 3. A fusion-derived cybrid plant appearing as a stable "thick skinned" (WWG) periclinal chimera with a leaf pattern showing a green center surrounded by a white margin. 4. Leaf pattern of a yellowish center of a "sandwich" (WGW) periclinal chimera is made apparent by light shone from behind the leaf. 5 A-E. Apparently normal green cybrid plants can be classed as "thin skinned" (WGG) periclinal chimeras by the appearance of adventitious albino lateral shoots $(\mathbf{A})$, white and variegated shoots in a leaf strip test $(\mathbf{B}$, left) on non-selective medium (complete bleaching on selective medium indicates streptomycin sensitivity), white streaks where the sepals grow together around the seed capsules (C, right), and no chloroplasts in the guard cells of the epidermis $(\mathbf{E})$ in contrast to the case of plants with a wild-type L1 layer (D) 
A

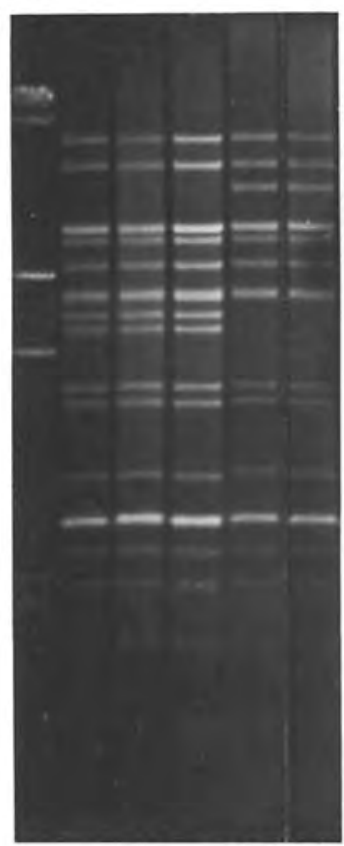

a b c d e

\section{B}

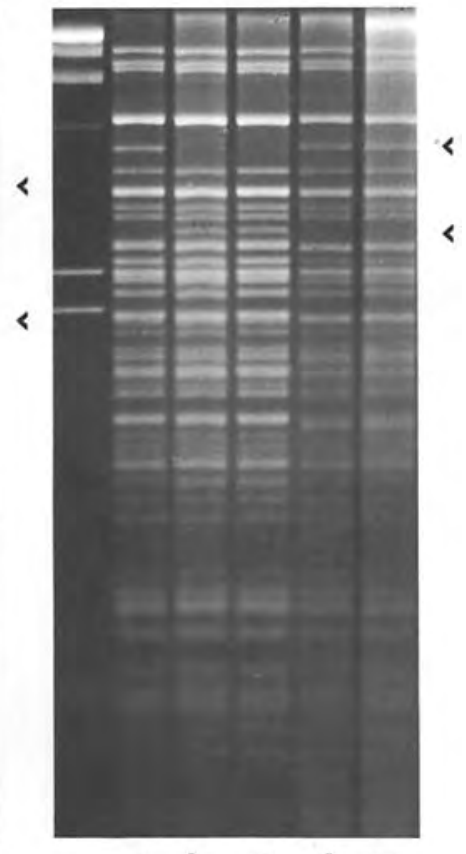

a b c d e

Fig. 6A, B. Xhol (A) and EcoRI (B) restriction endonuclease digestion patterns of plastid DNA of Nicotiana plumbaginifolia $(a), N$ plumbaginifolia TBR2 $(b)$, a green $(c)$ and a white $(e)$ fusion-derived regenerate, and N. tabacum SR-A15 (d). Lambda HindIII digests are also shown (first lanes). The appearance of a new EcoRI cutter site in the TBR2 plastome is most probably due to the mutagen treatment applied (Cséplö et al. 1985). The physical map of the SR-A15 plastome is identical to that of wild-type N. tabacum (Sváb and Maliga 1986)

and N. plumbaginifolia plastomes, and so were suitable for the demonstration of their DNA recombination (Medgyesy et al. 1985a), were tested for signs of a limited plastid DNA recombination in the regenerates. An analysis of the green and white plants, however, revealed the presence of unchanged $N$. plumbaginifolia TBR2 and $N$. tabacum plastid genomes, respectively, with XhoI (Fig. 6A), EcoRI (Fig. 6B), PstI, SmaI, and HindIII. Variegated plants showed simple additive restriction patterns (data not shown). The mitochondrial DNA restriction patterns obtained with $B g I$ demonstrated recombined chondriomes in both green and white regenerates (Fig. 7), as expected from their fusion origin.

\section{Discussion}

Protoplast fusion-derived cells are generally cultured for some weeks in a medium which strongly stimulates cell division and prevents greening. If the growing cell colonies, derived from a fusion of green and chlorophylldeficient plastid mutant protoplasts, are then transferred to a medium simultaneously stimulating greening and

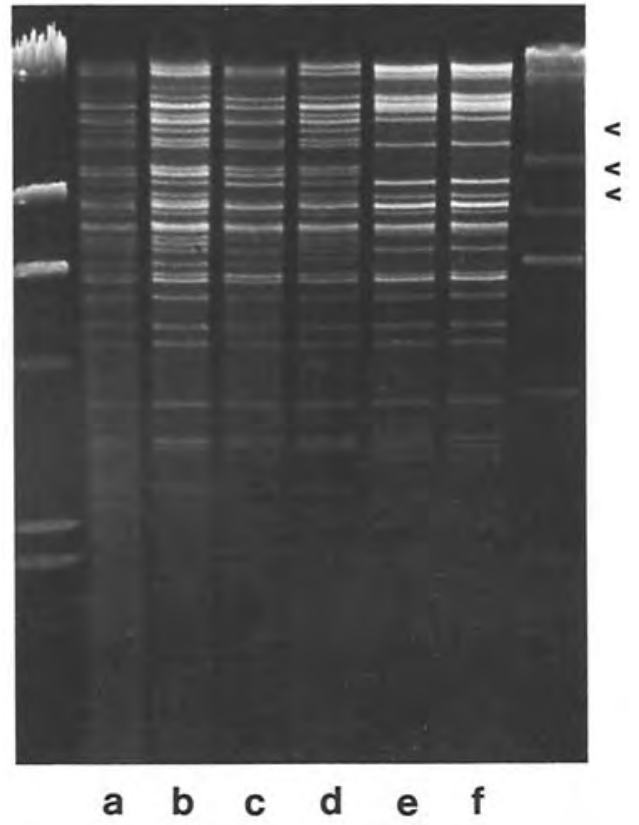

Fig. 7. $B g l \mathrm{I}$ restriction endonuclease digestion patterns of mitochondrial DNA of Nicotiana plumbaginifolia (a) N. plumbaginifolia TBR2 $(b)$, a green $(c)$ and a white $(d)$ fusion-derived regenerate, $N$. tabacum SR-A15 $(e)$ and SR1 $(f)$. A lambda HindIII digest (first lane) and a $B g l \mathrm{I}$ digest of $N$. tabacum plastid DNA (last lane) are also shown

organogenesis, it leads to $60-80 \%$ of the regenerated plants being white and/or variegated (Gleba 1979; Sidorov et al. 1981; Fluhr et al. 1984; Gleba et al. 1984), demonstrating an ongoing vegetative segregation at the time of shoot regeneration. However, allowing at least 2 months for greening of the heterokaryon-derived cell lines before organogenesis results in, at most, $5-6 \%$ variegated, among pure green, cybrid plants (Glimelius and Bonnett 1981; Medgyesy et al. 1985 b; Thanh et al. 1988). This demonstrates the termination of intracellular plastid segregation and the formation of pure cell lines prior to shoot regeneration. The data presented here indicate that, in addition to allowing enough time for segregation, a high light intensity is also essential to maintain sufficient selection pressure on the mixed plastid populations to result in the gradual domination of chloroplasts in subsequent cell generations. Considering the possible mechanism of light stimulation, active photosynthesis can be ruled out since Nicotiana calli grown on high sugar concentration medium are heterotrophic, show no photosynthetic activity, and grow in the same way in the light and the dark (Cséplö and Medgyesy 1986). Lightdependent expression of a number of nuclear genes coding for chloroplast proteins, however, is under transcriptional control by the stage of the plastid development (Taylor 1989). In sufficient light a plastidic factor which is expressed in chloroplasts only, may, therefore, stimulate cell metabolism. This, in turn, may facilitate the 
multiplication and segregation of chloroplasts in a mixed plastid population during the course of cell divisions.

Streptomycin is an inhibitor of bacterial-type protein biosynthesis (Davis 1987). Although streptomycin does not completely block the growth of sensitive plant cell cultures, streptomycin-resistant calli show a better growth in addition to their green colour (Maliga et al. 1973). Resistant growth and greening are both linked exclusively to the plastids, as has been demonstrated by the transfer of the chloroplasts, independently from mitochondria, using a sexual cybridization through the pollen (Medgyesy et al. 1986). The better growth ability of resistant calli is not dependent on light, as was demonstrated by the comparative growth of resistant and sensitive Nicotiana calli in the dark in the presence of streptomycin (Cséplö and Medgyesy, unpublished data). The experiment reported here, on the transfer of albino streptomycin-resistant plastids in the dark, confirms that the better multiplication rate of resistant plastids/cells is sufficient for an efficient selection of cybrid lines with an exchanged plastid population. The protein synthesizing ability of plastids seems to be of crucial importance for cell metabolism since the biosynthetic pathways leading to porphyrin and most amino acids are (at least partly) located in, and therefore dependent on, functional plastids (Lea et al. 1985; Howe and Smith 1991). In parasitic, achlorophyllous plants the plastid genome has lost the chloroplast genes for photosynthesis, but retained the genes necessary for the protein synthesizing machinery of the plastid (dePamphilis and Palmer 1990). The selective advantage of resistant plastids/cells in the dark, therefore, is understandable. Even so, the selection was not clearcut because of some ambiguity in the identification of vigorously growing colonies, and the appearance of sensitive subpopulations (green spots) in the selected calli when placed in the light. As described in the preceding section, selection for mere greening, although efficient in sufficient light, generally also results in some segregating (variegated) cybrids. Taken together these results suggest that, in the particular case of streptomycin selection in the light, there are two parallel advantages of the resistant chloroplasts for cell metabolism. These advantages, their ability for both protein synthesis and greening, result in the powerful selection pressure, by which pure cybrids, showing no signs of continuing plastid segregation, can be regularly obtained (Medgyesy et al. 1980; Menczel et al. 1982; Maliga et al. 1982).

The stability of the plastid DNA recombination product reported earlier (Medgyesy et al. 1985a) demonstrates that selection for plastid genetic markers also plays a key role in the production of a population of plastids with recombined plastomes. It is, therefore, curious that the linkage between the selected pair of genetic traits used in this latest attempt to achieve plastid DNA recombination was lost during plant regeneration. A pos- sible explanation is a basic leakiness of the selection allowing the greening of all cybrid colonies. The apparently resistant colony selected, however, appeared as a single green colony in the whole fusion-derived population, as in an earlier experiment revealing a real chloroplast DNA recombination (Thanh and Medgyesy 1989). Although their fusion origin was proven by their recombined mitochondrial genomes, the regenerated plants demonstrated a simple segregation of unchanged parental plastids. A phenotypic masking of the genetically independent sensitive plastids during cell selection can be excluded because streptomycin resistance is of a binding type in mutated plastids (Gravel et al. 1987; Etzold et al. 1987). However, antibiotic selection may be weakened at the beginning of shoot regeneration (unpublished observations). Sensitive cell colonies grown near to the surface of the agar medium, and the morphogenetic spots of sensitive (bleached) calli, therefore, might show a transitory but misleading greening on selective medium. In the experiment described here a combination of several factors, namely a late plastid segregation coupled with an early shoot regeneration, under a selection of low stringency caused by both the low light intensity and the shoot regeneration itself, most probably led to the segregation of pure parental plastid genomes, in spite of the selection for genetic recombination. In the earlier reports on plastome recombination, as a comparison of the selective conditions indicates, the stringency of the several months long cell selection in the light for greening (Thanh and Medgyesy 1989) or greening and streptomycin resistance (Medgyesy et al. 1985a) before shoot regeneration, resulted in the production of plants with stable, homogeneous populations of recombined chloroplasts.

Several factors influence the sorting-out of a genetically heterogeneous plastid population in plant cell cultures. As expected from studies on organelle genome segregation in unicellular organisms (Birky 1978), adequate time for vegetative segregation is a critical factor, even if there is a selection for a certain organelle type (Moll et al. 1990). Unlimited and disoriented cell divisions in culture, as contrasted to the limited proliferation in space and time in a morphogenetically determined structure (e.g., leaf expansion), strongly facilitate the better growth, and thus the visible appearance of, e.g., a resistant cell line, and the higher chance of shoot primordium formation from such a tissue. As our results indicate, stringent conditions favouring multiplication of the desired plastid population, most favourably by both light stimulation and preferential protein biosynthesis, are also essential elements for the efficient production of a stable plastid population with a uniform genetic composition.

Acknowledgements. The authors thank Ms. G. Szalma and Ms. A. Török for their technical assistance, B. Dusha for photogra- 
phy and Dr. L. Szabados for critical reading of the manuscript. The work was supported by an OKKFT/Tt grant No. 4430.

\section{References}

Akada S, Hirai A (1983) Studies on the mode of separation of chloroplast genomes in parasexual hybrid calli. II. Heterogeneous distribution of two kinds of chloroplast genomes in hybrid callus. Plant Sci Lett 32:95-100

Akada S, Hirai A, Uchimiya H (1983) Studies on the mode of separation of chloroplast genomes in parasexual hybrid calli. I. Fraction I protein composition in unseparated hybrid callus. Plant Sci Lett 31:223-230

Belliard G, Pelletier G, Vedel F, Quetier F (1978) Morphological characteristics and chloroplast DNA distribution in different cytoplasmic parasexual hybrids of Nicotiana tabacum. Mol Gen Genet 165:231-237

Birky CW (1978) Transmission genetics of mitochondria and chloroplasts. Annu Rev Genet 12:471-512

Bookjans G, Stummann BM, Henningsen KW (1984) Preparation of chloroplast DNA from pea plastids isolated in a medium of high ionic strength. Anal Biochem 141:244-247

Butterfass T (1979) Patterns of chloroplast reproduction. Springer Verlag, Wien

Chen K, Wildman SG, Smith HH (1977) Chloroplast DNA distribution in parasexual hybrids as shown by polypeptide composition of fraction I protein. Proc Natl Acad Sci USA 74:5109-51:12

Cséplö A, Maliga P (1984) Large scale isolation of maternally inherited lincomycin resistance mutations, in diploid Nicotiana plumbaginifolia protoplast cultures. Mol Gen Genet 196:407-412

Cséplö A, Medgyesy P (1986) Characteristic symptoms of photosynthesis inhibition by herbicides are expressed in photomixotrophic tissue cultures of Nicotiana. Planta 168:24-28

Cséplö A, Nagy F, Maliga P (1984) Interspecific protoplast fusion to rescue a cytoplasmic lincomycin resistance mutation into fertile Nicotiana plumbaginifolia plants. Mol Gen Genet 198:7-11

Cséplő A, Medgyesy P, Hideg E, Demeter S, Márton L, Maliga P (1985) Triazine-resistant Nicotiana mutants from photomixotrophic cell cultures. Mol Gen Genet 200:508-510

Davis BD (1987) Mechanism of bactericidal action of aminoglycosides. Microbiol Rev 51:341-350

dePamphilis CW, Palmer JD (1990) Loss of photosynthetic and chlororespiratory genes from the plastid genome of a parasitic flowering plant. Nature 348:337-339

Durbin RD, Uchytil TF (1977) A survey of plant insensitivity to tentoxin. Phytopathology 67:602-603

Etzold T, Fritz CC, Schell J, Schreier PH (1987) A point mutation in the chloroplast 16S rRNA gene of a streptomycin-resistant Nicotiana tabacum. FEBS Lett 219:343-346

Fluhr R (1983) The segregation of organelles and cytoplasmic traits in higher plant somatic fusion hybrids. In: Potrykus I, Harms CT, Hinnen A, Hütter R, King PJ, Shillito RD (eds) Protoplasts 1983. Lecture proceedings. Birkhäuser Verlag, Basel, pp 85-92

Fluhr R, Aviv D, Edelman M, Galun E (1983) Cybrids containing mixed and sorted-out chloroplasts following interspecific somatic fusions in Nicotiana. Theor Appl Genet 65:289-294

Fluhr R, Aviv D, Galun E, Edelman M (1984) Generation of heteroplastidic Nicotiana cybrids by protoplast fusion: analysis for plastid recombinant types. Theor Appl Genet $67: 491-497$
Gleba YY (1979) Nonchromosomal inheritance in higher plants as studied by somatic cell hybridization. In: Sharp W, Larsen PO, Paddock EF, Raghavan V (eds) Plant cell and tissue culture - principles and applications. Ohio State University Press, Columbus, pp 775-788

Gleba Y, Kolesnik NN, Meshkene IV, Cherep NN, Parokonny AS (1984) Transmission genetics of the somatic hybridization process in Nicotiana. I. Hybrids and cybrids among the regenerates from cloned protoplast fusion products. Theor Appl Genet 69:121-128

Glimelius K, Bonnett HT (1981) Somatic hybridization in Nicotiana: restoration of photoautotrophy to an albino mutant with defective plastids. Planta 153:497-503

Gravel M, Melancon P, Brakier-Gingras L (1987) Cross-linking of streptomycin to the 16S ribosomal RNA of Escherichia coli. Biochemistry 26:6227-6232

Howe CJ, Smith AG (1991) Plants without chlorophyll (correspondence). Nature 349:109

Lea PJ, Wallsgrove RM, Miflin BJ (1985) The biosynthesis of amino acids in plants. In: Barrett GC (ed) Chemistry and biochemistry of the amino acids. Chapman and Hall, London, pp 197-226

Maliga P, Breznovits A, Márton L (1973) Streptomycin-resistant plants from callus culture of haploid tobacco. Nature $244: 29-30$

Maliga P, Lörz H, Lázár G, Nagy F (1982) Cytoplast-protoplast fusion for interspecific chloroplast transfer in Nicotiana. Mol Gen Genet 185:211-215

Medgyesy P (1990) Selection and analysis of cytoplasmic hybrids. In: Dix PJ (ed) Plant cell line selection. VCH Publishers, Weinheim, pp 287-316

Medgyesy P, Menczel L, Maliga P (1980) The use of cytoplasmic streptomycin resistance: chloroplast transfer from Nicotiana tabacum into Nicotiana sylvestris, and isolation of their somatic hybrids. Mol Gen Genet 179:693-698

Medgyesy P, Fejes E, Maliga P (1985 a) Interspecific chloroplast recombination in a Nicotiana somatic hybrid. Proc Natl Acad Sci USA 82:6960-6964

Medgyesy P, Golling R, Nagy F (1985 b) A light-sensitive recipient for the effective transfer of chloroplast and mitochondrial traits by protoplast fusion in Nicotiana. Theor Appl Genet 70:590-594

Medgyesy P, Páy A, Márton L (1986) Transmission of paternal chloroplasts in Nicotiana. Mol Gen Genet 204:195-198

Melchers G, Sacristán MD, Holder AA (1978) Somatic hybrid plants of potato and tomato regenerated from fused protoplasts. Carlsberg Res Commun 43:203-218

Menczel L, Nagy F, Kiss Z, Maliga P (1981) Streptomycin-resistant and sensitive somatic hybrids of Nicotiana tabacum + Nicotiana knightiana: correlation of resistance to N. tabacum plastids. Theor Appl Genet 59:191-195

Menczel L, Galiba G, Nagy F, Maliga P (1982) Effect of radiation dosage on efficiency of chloroplast transfer by protoplast fusion in Nicotiana. Genetics 100:487-495

Menczel L, Polsby LS, Steinback KE, Maliga P (1986) Fusionmediated transfer of triazine-resistant chloroplasts: characterization of Nicotiana tabacum cybrid plants. Mol Gen Genet 205:201-205

Moll B, Polsby L, Maliga P (1990) Streptomycin and lincomycin resistances are selective plastid markers in cultured Nicotiana cells. Mol Gen Genet 221:245-250

Murashige T, Skoog F (1962) A revised medium for rapid growth and bioassays with tobacco tissue cultures. Phys Plant 15:473-497

Nagy JI, Maliga P (1976) Callus induction and plant regeneration from mesophyll protoplasts of Nicotiana sylvestris. Z Pflanzenphysiol 78:453-455 
Purnhauser L, Medgyesy P, Czakó M, Dix PJ, Márton L (1987) Stimulation of shoot regeneration in Triticum aestivum and Nicotiana plumbaginifolia tissue cultures using the ethylene inhibitor $\mathrm{AgNO}_{3}$. Plant Cell Rep 6:1-4

Sambrook J, Fritsch EF, Maniatis T (1989) Molecular cloning: a laboratory manual. Cold Spring Harbor Laboratory, Cold Spring Harbor, New York

Sidorov VA, Menczel L, Nagy F, Maliga P (1981) Chloroplast transfer in Nicotiana based on metabolic complementation between irradiated and iodoacetate-treated protoplasts. Planta 152:341-345

Sváb Z, Maliga P (1986) Nicotiana tabacum mutants with chloroplast-encoded streptomycin resistance and pigment deficiency. Theor Appl Genet 72:637-643

Taylor WC (1989) Regulatory interactions between nuclear and plastid genomes. Annu Rev Plant Physiol Plant Mol Biol 40:211-233
Thanh ND, Medgyesy P (1989) Limited chloroplast gene transfer via recombination overcomes plastome-genome incompatibility between Nicotiana tabacum and Solanum tuberosum. Plant Mol Biol 12:87-93

Thanh ND, Páy A, Smith MA, Medgyesy P, Márton L (1988) Intertribal chloroplast transfer by protoplast fusion between Nicotiana tabacum and Salpiglossis sinuata. Mol Gen Genet 213:186-190

Tilney-Bassett RAE (1978) The inheritance and genetic behaviour of plastids. In: Kirk JTO, Tilney-Bassett RAE (eds) The plastids. Elsevier/North-Holland Biomedical Press, Amsterdam, pp 251-524

Tilney-Bassett RAE (1986) Plant chimeras. Edward Arnold, London 